\title{
Estimation of Syphilis Serostatus on the Safety of Infertile Patients
}

\author{
Alaa Hamza Jaber Al-Jelehawy ${ }^{1}$, Qassim Muhsin Hashim Al-Faham², \\ Zainab Hassan Hadi Al-Saadi ${ }^{3}$, Saif Jabbar Yasir ${ }^{4}$, Ammar Kareem Kadhim Al-Furaiji ${ }^{5}$ \\ ${ }^{1}$ Assistant Lecturer, Master, Department of Medical Laboratories Techniques, Altoosi University College, \\ Iraq, ${ }^{2}$ Lecturer, Doctorate, Department of Medical Laboratories Techniques, Altoosi University College, Iraq, \\ ${ }^{3}$ Researcher, Master, Associate Chief Bacteriology, Ministry of Health, Bagdad-Iraq, ${ }^{4}$ Professor, Doctorate, \\ Department of Medical Microbiology, Faculty of Medicine, University of Kufa, ${ }^{5}$ Assistant Lecturer, Master, \\ Department of Quality Assurance, Ministry of Higher Education and Scientific Research
}

\begin{abstract}
Background: Infertility is a case assuming approximately 15 percent of couples in the world. At Italy, the evaluated percentage increases to 20 percent. There are many reasons for this case, among that a significant function appears to be manipulated by infections of the genital tract.
\end{abstract}

Aim of the Study: For assessments the influence of syphilis on the safety of infertile patients.

Materials and Method: All specimens of serum were initial evaluated utilizing a non-Treponema pallidum serologic(Ag) analysis to estimated for syphilis disease, \& then a Treponema pallidum serologic (Ag) analysis was proceed to assert the positive specimen of syphilis recognized via the checking test.

Results: a total of 137 cases of infertile patients were collected ( 83 cases in male, 54 cases in female), from 83 cases of infertile male founded that 20 cases were suspected to T. pallidum infection while from 54 case of infertile female were founded that 15 cases were suspected to infection with Treponema pallidum bacteria. Also these results show that patients with continuous infertility have significant level of $T$. pallidumin females with age 41-50 years (54.55) while males with age 31- 40 years (34.62) than the age suspected for T. pallidum is $>$ or $=41$ years.

Conclusions: A positive date of syphilis contagion may decrease the average of clinical gestation by sexual contact. Also, this decreasing in the average of clinical gestation needs a diversity of agents, including density of endometrial, grown oocytes number, the number of pollinated, splited oocytes under normal conditions, \& the average of implantation.

Keywords: Infertility, T. pallidum, syphilis disease (STD), in vitro fertilization, rapid plasma regain, TPPA test.

\section{Introduction}

Infertility is a case assuming approximately 15 percent of couples in the world ${ }^{[1]}$. At Italy, the evaluated

\section{Corresponding Author:}

\section{Alaa Hamza Jaber Al-Jelehawy}

Assistant Lecturer, Master, Department of Medical

Laboratories Techniques, Altoosi University College, Iraq

e-mail: alaa_hamza@altoosi.edu percentage increases to 20 percent $^{[2]}$. There are many reasons for this case, among that a significant function appears to be manipulated by infections of the genital tract ${ }^{[3]}$.Infertility of human is known as the insufficiency for a couple to visualize \& yield individuals after at minimal 12 successive months of not protected erotic contact. Infertility is a condition of complicated health in human which specifically changes the fineness of sustenance in couples meeting the situation. In 2010, approximately 1.9 percent \& 10.5 percent of female reproductive age (20-44 years) were influenced via 
initial \& minor infertility respectively. Prevalence of a rising infertility is appeared in South Asia, and Africa ${ }^{[3]}$.

However, there are several agents that are responsible for weakness of sexual role of fertility in male $\&$ female. These agents involve disorders in hormone, condition of psychological. Every these agents can lead to weakness in the genital organs function, the reproductive cells production, quality of semen, transport cell of sperm to the oocyte, fruitfulness \& stages of implantation in embryo ${ }^{[4,5]}$. However, syphilis can be defined as is a disease transmitted by sexual contact caused by bacterium $T$. pallidum, \& it sfirstly prevalence through sexual contact, from blood or from mother to fetus ${ }^{[6]}$.

Also, infection of reproductive tract can cause approximately 8 percent $\& 35$ percentofevery situations of man infertility, respectively ${ }^{\text {[7] }}$. In female, it may result in obstruction of fallopian channel $\&$ inflammation of endometrium. Approximately 72.4 million people in the world have problems of infertility. Also, in vitro fertilization may be the end refuge for couples trying to control infertility ${ }^{[8]}$. On the other hand, if syphilis disease is left without treatment, the illness may continue for years \& result in the incidence of severe complications, as well as granulomas, and paralysis ${ }^{[9]}$.

Also, Pregnant female which is infected with this disease may transport $T$.pallidum to the fetus, $\&$ this leads to reverse consequences of pregnancy,including stillbirth, fetus deaths ${ }^{[10]}$.On the other hand, testing of syphilis, connected with suitable and stimulate treatment of penicillin for infected patients, is proposed by the World Health Organization to stop syphilis transportation ${ }^{[11]}$.

\section{Materials and Method}

Selection of Patients: Couples which flopped to conceive after minimum one year of sexual contact without contraception were deemed to be infertile. Infertility was caused by dysfunction of fallopian channel \& factors related to man (a detection of asthenozoosperimiadepending on the World Health Organization laboratory manual for the investigation ${ }^{[12,13]}$.
Every patients afford new ET through the initial rotation $\&$ didn't acquire any treatment for three months before in vitro fertilization. However,patients were precluded if they had ovary tumor, multiple cyst ovarian disorder, disease of thyroid gland, disease of adrenal gland, and diabetes.

Function of ovarian was investigated, and specimen of blood were collected on 2-4 days of menses to investigate the main $\mathrm{FSH}, \mathrm{LH}, \&$ levels of estrogen. Also, tests of sperm phenotype was managed ${ }^{[14]}$. Every participants received serological investigations in the laboratory (the rapid plasma regain [RRR] and agglutination of $T$. pallidum particle tests [TPPA]) to test for the existence infection of syphilis before the treatment of in vitro fertilization.

Test of syphilis: All specimens of serum were initial evaluated utilizing a non -Treponema pallidum serologic (Ag) analysis to estimated for syphilis disease, $\&$ then a Treponema pallidum serologic (Ag) analysis was proceed to assert the positive specimen of syphilis recognized via the checking test ${ }^{[15,16,17]}$. For the rapid plasma regain test, cardiolipin is applied as an Ag to discover antibodies directed against cardiolipin in the patientsserum ${ }^{[18]}$.Every specimens of serum for the rapid plasma regain test were gradually diluted $(1: 1-1: 32)$ in natural saline solution for titer definition ${ }^{[19]}$.In the $T$. pallidum particle agglutination test, granules of gelatin sensitive to $T$. pallidum attach to antibodies against $T$. pallidum in the human serum. The collections of the rapid plasma regain $\& T$. pallidum particle agglutination tests is commonly utilized to the identifying of syphilis through every stages of the illness with appropriate susceptibility \& particularity ${ }^{[20]}$.

\section{Results}

Demographic features of the patient specimen: SPSS (version 21) was utilized to analyze the current data. Important differences were acquired by utilizing the chi-squared test. Differences between variables were setting as significant in 5\% $(\mathrm{P} \leq 0.05)$ \& hardly Significant in $1 \%(\mathrm{P} \leq 0.01)$. 
Table (1): Explain infertile patient \& related to the $T$. pallidum with male and female:

A. Classification cases of infertile patients into male and female (Total=137 cases, 83 cases in male, 54 cases in female).

\begin{tabular}{|l|c|c|c|c|c|c|}
\hline \multirow{2}{*}{ Age groups } & \multirow{2}{*}{$\begin{array}{c}\text { No. of cases. } \\
\text { infertile patients }\end{array}$} & \multicolumn{2}{|c|}{ Male } & \multicolumn{2}{|c|}{ Female } & P value \\
\cline { 3 - 7 } & 66 & 42 & 63.64 & F & 24 & 36.36 \\
\hline $20-30 \mathrm{yrs}$ & 45 & 26 & 57.78 & 19 & 42.22 & $0.024 *$ \\
\hline $31-40 \mathrm{yrs}$ & 26 & 15 & 57.69 & 11 & 42.31 \\
\hline $41-50 \mathrm{yrs}$ & $\mathbf{1 3 7}$ & $\mathbf{8 3}$ & & $\mathbf{5 4}$ & & \\
\hline Total & 66 & & & \\
\hline
\end{tabular}

$*$ =significant at $\mathrm{P} \leq 0.05$, Chi-squared test, $\mathrm{df}, 5, \alpha=0.05$

B. Male infertile patients suspected to $T$. pallidum (Total=20 cases)

\begin{tabular}{|l|c|c|c|c|c|c|}
\hline \multirow{2}{*}{ Age groups } & \multirow{2}{*}{$\begin{array}{c}\text { No. of cases } \\
\text { infertile Male }\end{array}$} & \multicolumn{2}{|c|}{ T. Pallidum + } & \multicolumn{2}{c|}{ T. Pallidum - } & P value \\
\cline { 3 - 7 } & & M & \% & M & 92.86 \\
\hline 20-30yrs & 42 & 3 & 7.14 & 39 & 65.38 \\
\hline $31-40 y r s$ & 26 & 9 & 34.62 & 17 & 46.67 \\
\hline $41-50 y r s$ & 15 & 8 & 53.33 & 7 & & $<0.01 * *$ \\
\hline Total & $\mathbf{8 3}$ & $\mathbf{2 0}$ & & & \\
\hline
\end{tabular}

$* *=$ significant at $\mathrm{P} \leq 0.05$, Chi-squared test, $\mathrm{df}, 5, \alpha=0.01$

C. Female infertile patients suspected to $T$. pallidum (Total=15 cases).

\begin{tabular}{|l|c|c|c|c|c|c|}
\hline \multirow{2}{*}{ Age groups } & \multirow{2}{*}{$\begin{array}{c}\text { No. of cases } \\
\text { infertile female }\end{array}$} & \multicolumn{2}{|c|}{ T. Pallidum + } & \multicolumn{2}{|c|}{ T. Pallidum - } & \multirow{2}{*}{ P value } \\
\cline { 3 - 6 } & & F & $\mathbf{\%}$ & F & 91.67 \\
\hline $20-30 y r s$ & 24 & 2 & 8.33 & 22 & 63.16 & $<0.01 * *$ \\
\hline $31-40 y r s$ & 19 & 7 & 36.84 & 12 & 45.45 \\
\hline T1-50yrs & 11 & 6 & 54.55 & 5 & & \\
\hline
\end{tabular}

$* *=$ significant at $\mathrm{P} \leq 0.05$, Chi-squared test, $\mathrm{df}, 5, \alpha=0.01$

In the above table, a total of 137 cases of infertile patients were collected ( 83 cases in male, 54 cases in female), from 83 cases of infertile male founded that 20 cases were suspected to T. pallidum while from 54 case of infertile female were founded that 15 cases were suspected to infection with Treponema pallidum bacteria. Also these results show that patients with continuous infertility have significant level of $T$. pallidum in females with age 41-50 years(54.55) while males with age 31- 40 years (34.62) than the age suspected for infection with $T$. pallidum is $>$ or $=41$ years.

\section{Discussion}

This survey was directed to estimate the appearance of infections in couples with problems of fertility in Iraq.
Urogenital tract inflammations are indirectly or directly a main reason of infertile patients in couples since they can damage the genital organ either in female \& male, $\&$ because $T$. pallidum can perform to the motile sperm agglutination, a modifications in the morphological characteristics of the cell ${ }^{[21,22]}$.

However, the patients plurality were negative \& the percent of positive subject was elevated in male and female. Furthermore, in female there are a vast diversity of bacterial types responsible for the infections compare to man. Both these forms can be demonstrated regarding that female is more sensitive to infections of genitourinary tract because the urethra of female is wider and smaller compare to the urethra in the man \& 
because the vaginal region nearly the vaginal cavity is colonized with potential pathogen.

Also, infection with $T$. pallidum, the bacteria causing syphilis that is a general cause infertility in $\operatorname{man}^{[23]}$. Human immunodeficiency virus-seropositive female have been observed to be co-infectedwith the $T$. pallidum, and human papillomavirus ${ }^{[24]}$.

However, there is a connection between sex steroids $\&$ danger factors of cardiovascular system, quality of semen, and levels of lipid ${ }^{[25]}$. Low-densitylipoprotiencholesterol and seminal plasma triglyceride may be useful biochemical signals for evaluating infertility in $\operatorname{man}^{[26]}$.

A rising number of infertility in patients require aided genital technology treatments. Patients are exposed for viruses \& bacteria, as well as $\mathrm{HCV}$, cytomegalovirus, HIV, T. pallidum, and Chlamydia trachomatis before aided genital technology depending on the European community of person proliferation ${ }^{[27]}$.

At least $90 \%$ of female is investigated for syphilis disease before birth \& 90 percent of seropositive pregnant male acquire appropriate treatment ${ }^{28]}$.

Syphilis (as an sexual transmitted disease)may cause pelvic inflammation, that may lead to impairment of endometrium. Moreover, this deterioration produces renewal method, which may thicken the lining of endometrium \& lead to functioning of abnormal endometrium \& decreased receptivity of endometrium, producing infertility ${ }^{[29,30]}$.

Every female must be investigated for T.pallidum through the initial investigation before birth $\&$ again in gestation but late ${ }^{[31]}$.

In addition, cytokines and anti-cytokineantibody may influence the fertility of patients infected with syphilis toa particular extent. Also, ACAs are usually present in the patients serum \& can suppress the segregation of Langhans layer into syntiotrophoblasts, therapy detrimental cultivated blastocysts which have clusters of an internal cells that forms fetus ${ }^{[32]}$. However, cytokines are carefully linked to all guise of the genital procedure \& can be utilized to foretell the clinical consequence in vitro fertilization ${ }^{[33]}$.

\section{Conclusions}

A positive date of syphilis contagion may decrease the average of clinical gestation by sexual contact. Also, this decreasing in the average of clinical gestation needs a diversity of agents, including density of endometrial, grown oocytes number, the number of pollinated, splitedoocytes under normal conditions, \& the average of implantation.

Ethical Clearance: Ethics committee refer there is no plagiarism and there is no mistakes or wrong results in this work.

Conflict of Interest: The authors reported there are no collision of interest.

Founding Source: None.

\section{References}

1. Mascarenhas, M.N.; Flaxman S.R.; Vanderpoel, S. et al. National, regional and global trends in infertility prevalence since 1990: A systematic analysis of 277 health surveys. PloS Med. 2012; 9.

2. Istituto Superiore di Sanità. Registro Nazionale Procreazione Medicalmente Assistita. 2015.

3. Novy, M.; Eschenbach, D. et al. Glob Libr Women's Med. 2008.

4. Abrao, M.S.; Muzii L.; Marana, R. Anatomical causes of female infertility and their management. Int J Gynaecol Obstet. 2013;(123): S18-24.

5. Inoue, S.; Tomasini, R.; Rufini,; A. et al. TAp73 is required for spermatogene- sis and the maintenance of male fertility. Proc Natl Acad Sci USA. 2014;(111): 1843-1848.

6. Lee, S.H.; Kim, J.H.; Kim, S.C. Early congenital syphilis presenting with vesicobullous eruptions beyond palmoplantar regions. Acta Derm Venereol. 2014; 94(3):321-322.

7. Askienazy-Elbhar, M. Male genital tract infection: the point of view of the bacteriologist. Gynecol Obstet Fertil. 2005; 33(9):691-697.

8. Jin, X.; Wang, G.; Liu, S.; Zhang, J.; Zen, F.; Qiu, $Y$.; et al.Survey of the situation of infertile women seeking in vitro fertilization treatment in China. Biomed Res Int. 2013; 179098:10. 
9. Blencowe, H.; Cousens, S.; Kamb, M.; Berman, S.; Lawn, J.E.Lives Saved Tool supplement detection and treatment of syphilis in pregnancy to reduce syphilis related stillbirths and neonatal mortality. BMC Public Health. 2011;11 (3): S9.

10. Newman, L.;Kamb, M.; Hawkes, S.; Gomez, G.; Say, L.; Seuc, A.; Broutet, N. Global estimates of syphilis in pregnancy and associated adverse outcomes: analysis of multinational antenatal surveillance data. PLOS MED. 2013; 10: e1001396.

11. Kahn, J.G.; Jiwani, A.; Gomez, G.B.; Hawkes, S.J.; Chesson, H.W.; Broutet, N.;Kamb, M.L.; Newman, L.M. The cost and cost effectiveness of scaling up screening and treatment of syphilis in pregnancy: a model. PLOS ONE. 2014; 9: e87510.

12. WHO.WHO laboratory manual for the Examination of Human Semen and Semen-Cervical Mucus Interaction 4th edn. Cambridge: Cambridge University Press. 1999; 204.

13. WHO.WHO laboratory manual for the Examination and processing of human semen 5th edn. Geneva;World Health Organization. 2010; 224.

14. Lam, P.M.; Suen, S.H.; Lao, T.T.; Cheung, L.P.; Leung, T.Y.; Haines, C. Hepatitis B infection and outcomes of in vitro fertilization and embryo transfer treatment. Fertil Steril. 2010; 93(2):480485 .

15. Lee, V.; Kinghorn, G. Syphilis: an update. Clin Med. 2008;8(3):330-333.

16. Workowski, K.A.; Berman, S.Sexually transmitted diseases treatment guidelines. MMWR Recomm Rep. 2010; 59(RR-12):1-110.

17. Jiang, C.; Zhao, F.; Xiao, J.; Zeng, T.; Yu, J.; Ma, X.; et al. Evaluation of the recombinant protein $\mathrm{TpF} 1$ of Treponema pallidum for serodiagnosis of syphilis. Clin Vaccine Immunol. 2013; 20(10):1563-1568.

18. Sena, A.C.; White, B.L.; Sparling, P.F. Novel Treponema pallidum serologic tests: a paradigm shift in syphilis screening for the 21 st century. Clin Infect Dis. 2010; 51(6):700-708.

19. Tong, M.L.; Lin, L.R.; Liu, G.L.; Zhang, H.L.; Zeng, Y.L.; Zheng, W.H.; et al. Factors associated with serological cure and the serofast state of HIV-negative patients with primary, secondary, latent, and tertiary syphilis. PLOS ONE. 2013; 8(7):e70102 -10.
20. Smit, P.W.; Mabey, D.; Changalucha, J.; Mngara, J.; Clark, B.; Andreasen, A,;et al. The trade-off between accuracy and accessibility of syphilis screening assays. PLOS ONE. 2013; 8(9):e75327 -10 .

21. Sleha, R.; Bostikova, V.; Salavec, M.; et al. Bacterial infection as a cause of infertility in humans. Epidemiol Mikrobiol Imunol. 2013;62: 26-32.

22. Moretti, E.; Capitani, S.; Figura, N.; et al. J Assist Reprod Genet. 2009;26: 47-56.

23. Nester, E.W. D.G.; Anderson, C.E.; Roberts, N.N.; Pearsall, M.T., Nester, and D. Hurley. Microbiology: A Human Perspective. McGraw Hill Companies Inc., Boston. 2004; 817.

24. Sagna, T.F.; Djigma, M.;Zeba, C.;Bisseye, and S.D. Karou.; et al. Human papillomaviruses prevalence and genital co-infection in HIV-seropositive women in Ouagadougou (Burkina Faso). Pak. J. Biol. Sci. 2010; 13: 951-955.

25. Padron, R.S.;J. Mas, R.; Zamora, F.;Riverol, M.; Licea, L.;Mallea and J. Rodriquez. Lipid and testicular function. Int. Urol. Nephrol. 1989; 21: 515-519.

26. Olukaipe, I. Lipid profile of some infertile Nigerian males. M.Sc. Thesis, University of Ibadan, Ibadan, Nigeria. 2000.

27. Steyaert, S.R.; Leroux-Roels, G.G.;Dhont, M. Infections in IVF: review and guidelines. Hum. Reprod. Update. 2000;6: 432-441.

28. Berman, S.M. Maternal syphilis: pathophysiology and treatment. Bull. World Health Organ. 2004; 82: 433-438.

29. Cicinelli, E.; De Ziegler, D.; Nicoletti, R.;Tinelli, R.; Saliani, N.;Resta, L.; Bellavia, M.; et al. Poor reliability of vaginal and endocervical cultures for evaluating microbiology of endometrial cavity in women with chronic endometritis. Gynecol Obstet Invest .2009; 68(2):108-115.

30. Kasius, J.C.; Broekmans, F.J.; Sie-Go, D.M.; Bourgain, C.; Eijkemans, M.J.; Fauser, B .C.; et al. The reliability of the histological diagnosis of endometritis in asymptomatic IVF cases: a multicenter observer study. Hum Reprod. 2012; 27(1):153-158.

31. U.S. PSTF. Screening for syphilis infection in pregnancy: U.S. Preventive Services Task Force 
reaffirmation recommendation statement. Ann Intern Med. 2009; 150(10):705-709.

32. Di SN.; Meroni, P.L.; de Papa, N.; Raschi, E.; Caliandro, D.; De Carolis, C.S.; et al. Antiphospholipid antibodies affect trophoblast gonadotropin secretion and invasiveness by binding directly and through adhered beta2-glycoprotein I. Arthritis Rheum. 2000; 43(1):140-150.

33. Hammadeh, M.E.;Ertan, A.K.; Zeppezauer, M.; Baltes, S.; Georg, T.; Rosenbaum, P.; et al. Immunoglobulins and cytokines level in follicular fluid in relation to etiology of infertility and their relevance to IVF outcome. Am J Reprod Immunol. 2002; 47(2):82-90. 